SOCIAL RESEARCH REPORTS

ISSN: 2066-6861 (print), ISSN: 2067-5941 (electronic)

\title{
ADAPTATION AND VALIDATION OF THE LEARNING STYLES QUESTIONNAIRE - VARK TO MIDWIFERY EDUCATION - ME-VARK
}

\section{Zofia RAPAPORT, Stefan COJOCARU}

Social Research Reports, 2019, Vol. 11, Issue 3, pp. 108-123

The online version of this article can be found at:

www. researchreports.ro

\section{https://doi.org/10.33788/srr11.3.8}

Published by:

Expert Projects Publishing House

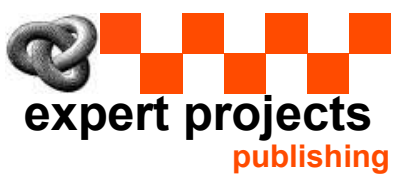

Covered by Index Copernicus International www.indexcopernicus.com

Directory of Open Access Journals www.doaj.org

On behalf of:

Center for Program and Social Development

Aditional services and information about Social Research Reports can be found at: www.researchreports.ro 


\title{
ADAPTATION AND VALIDATION OF THE LEARNING STYLES QUESTIONNAIRE - VARK TO MIDWIFERY EDUCATION - ME-VARK
}

\author{
Zofia RAPAPORT ${ }^{1}$, Stefan COJOCARU ${ }^{2}$
}

\section{Abstract}

The research objective is to adapt and validate the VARK questionnaire on learning styles (Fleming, 2001, 2008) to the discipline of midwifery education in nursing - ME-VARK. The four major learning styles are: Visual, Auditory Read/ write and Kinesthetic. From a sociological point of view, the working relationship between preceptor (midwife) and preceptee (student) contributes to the student's professional learning (self-efficacy in midwifery) and to the social formation of the students' identity as a midwifery practitioner. Therefore, matched learning styles between them are important for successful training, particularly in clinical practice. In order to construct the ME-VARK, following an in-depth literature review, and a documental analysis, a focus group and a Delphi procedure with in-depth literature review interviews were used to expose the subjective meanings of preceptorship relations as a social construct. Three expert-midwives that also were experienced preceptors participated in the focus group, and ten expert judges participated in six Delphi rounds (a total of 15 judgements). They were requested to propose items/responses relevant to midwifery education and then to validate the new ME-VARK. The results indicate that the chosen items are suitable to measure knowledge, competencies and learning styles in midwifery education. The adapted ME-VARK is relevant to midwifery education and encompasses the main labor stages, the central types of learning via preceptorship, and the essential topics in midwifery profession (exclusiveness). All items are relevant only to midwifery education (inclusiveness). The adapted ME-VARK was found to have all psychometric attributes: Content and construct validity, as well as face validity.

Keywords: midwifery education, preceptorship, learning styles, questionnaire adaptation and validation, Delphi method.

${ }^{1}$ Director of the Center For Advanced Nursing Education Near Rambam Medical Center, Haifa, ISRAEL; Department of Sociology and Social Work, Alexandru Ioan Cuza University, Iasi, ROMANIA. E-mail: z_rapaport@rambam.health. gov.il (Corresponding Author)

${ }^{2}$ Department of Sociology and Social Work, Alexandru Ioan Cuza University, Iasi, ROMANIA. E-mail:contact@stefancojocaru.ro 


\section{Introduction}

The research objective is to adapt and validate the VARK questionnaire (Fleming, 2001, 2008) to the discipline of midwifery education in nursing - ME-VARK. From a sociological point of view, the working relationship between preceptor (midwife) and preceptee (student) contributes to the student's professional learning (self-efficacy in midwifery) and to the social formation of the students' identity as midwifery practitioners (Phillips 2002; Phillips, Fawns, \& Hayes, 2002). The social construction theory refers to conversations and dialogues in which the preceptees are engaged with their midwife-preceptors that are a public form of reflective practice (Phillips \& Hayes, 2006), i.e., midwifery education.

\section{Midwifery education}

The role of the midwife has evolved worldwide from an unstructured occupation into a distinct profession, with clear professional boundaries, which are achieved through training, education and licensure. As a profession, midwifery has evolved to a socially constructed professional practice due to macro and micro sociocultural factors, which have played a key-role in these transitions (Benoit et al., 2005). A midwifery licensure in Israel is accessible only for registered nurses with a B.Sc. degree who have finished four years of studying in nursing faculty. The learning process is one year, and qualified midwives must pass the government examination and get a personal license.

The aim of midwifery education is to qualify competent and autonomous midwives (ICM, 2018; The World Health Organization, 2000; Lukasse Lilleengen, Fylkesnes, \& Henriksen, 2017), to empower professionalism based on the philosophical point of view that "care" has always been a woman-centered phenomenon. As such, it requires acknowledging and addressing significant sociocultural, economic and professional barriers that are rooted in gender inequality, visible in social and institutional hierarchies of power. However, competence is demonstrated when students successfully perform activities in a 'real world' clinical situation (Eraut, 2007). A midwife is trained to provide the necessary care to conduct normal deliveries on her own, recognize warning signs of abnormal or potentially abnormal conditions which necessitate referral to doctors, and help reduce unnecessary medical interventions (Bluff \& Holloway, 2008).

The aim of the Preceptorship model is to create and promote professional clinical competency in midwifery, and to assist and support students integrate theory into their clinical practice (Altman, 2006; Carlson, Wann-Hansson, \& Pilhammar, 2009; Phillips, 2016), as a professional role model (Perry, 2009; Power \& Ewing, 2016). Role theory, in sociology, concerns one of the most important features of social life, characteristic behavior patterns or roles (Biddle, 1979, 1986). Robert K. Merton (1959), who coined the term "role model", hypothesized that individuals compare themselves to relevant reference groups of people who occupy the social role to which they aspire (see also Holton, 2004). Preceptorship is defined as the relationship between preceptors (role models) and one or two preceptee for a bounded period (Lambert \& Glacken, 2006; Myric, 2002; Myric \& Young, 2004; Nielsen et al., 2017; Phillips et al., 2002). The preceptor is an 
expert clinician, i.e., midwife, who is familiar with the ward routine and culture and therefore can provide direct supervision and feedback according to the preceptee's learning needs, her level of confidence, and ability to think critically (Shamian \& Inhaber, 1985). In other words, the preceptor supports the preceptees in making the transition from novice to expert (Benner, 2001), and in socializing into the role of a professional midwife (Altman, 2006; Happell, 2009; Hardymen \& Hickey, 2001; Myrick, 2002; Myrick \& Yonge, 2001, 2004; Zilembo \& Monterosso, 2008). This process relies on the notion that social cognitive learning requires observation (Bandura, 1977). It has been suggested that matching the preceptee's and preceptor's learning styles may contribute to their relationship (Zilembo \& Monterosso, 2008).

\section{Learning styles - VARK}

The VARK questionnaire (Fleming, 2001, 2008) has been used for the last 30 years to identify types of learning styles (Peyman et al., 2014). It exhibits 16 daily-life situations which require learning but are irrelevant to midwifery education. Although it has been used in many studies for identifying students' learning styles and has been validated in several studies, (e.g., Felder \& Barnett, 2005; Leite, Svinicki, \& Shi, 2010), there is a need to adapt it to other disciplines, in the current study - midwifery education. Flemings' theory of Learning Styles describes four major types: Visual (learning by seeing), Auditory (learning by hearing), Read/write and Kinesthetic (learning by doing). Matched learning styles between a preceptor and preceptee are important for successful training (Hardy \& Smith, 2001), particularly in the nursing preceptor-preceptee relationship the clinical setting (Alkhasawneh, Maryyan, Alashram, \& Yousef, 2008; Cavanagh \& Coffin, 1994).

\section{Methodology}

\section{Research questions}

(1) Which items are suitable to measure knowledge, competencies and learning styles in midwifery education?

(2) What are the psychometric attributes of the adapted ME-VARK?

\section{Research approach}

According to the constructivist worldview, the aim of this study is to reveal how learning styles are perceived by a culture-sharing group (Creswell, 2014; Crotty, 1998), i.e. - expert experienced midwife preceptors. The social construct of learning styles in preceptorship relations is revealed using a focus group, Delphi procedure with interview, in order to construct and validate the ME-VARK according to their subjective meanings. The interpretive framework of social constructivism relies on an epistemological belief, according to which the reality 
that is constructed between the researcher and the investigated topic is formed by cumulative experiences of individuals (Creswell \& Poth, 2018).

\section{Design and procedure}

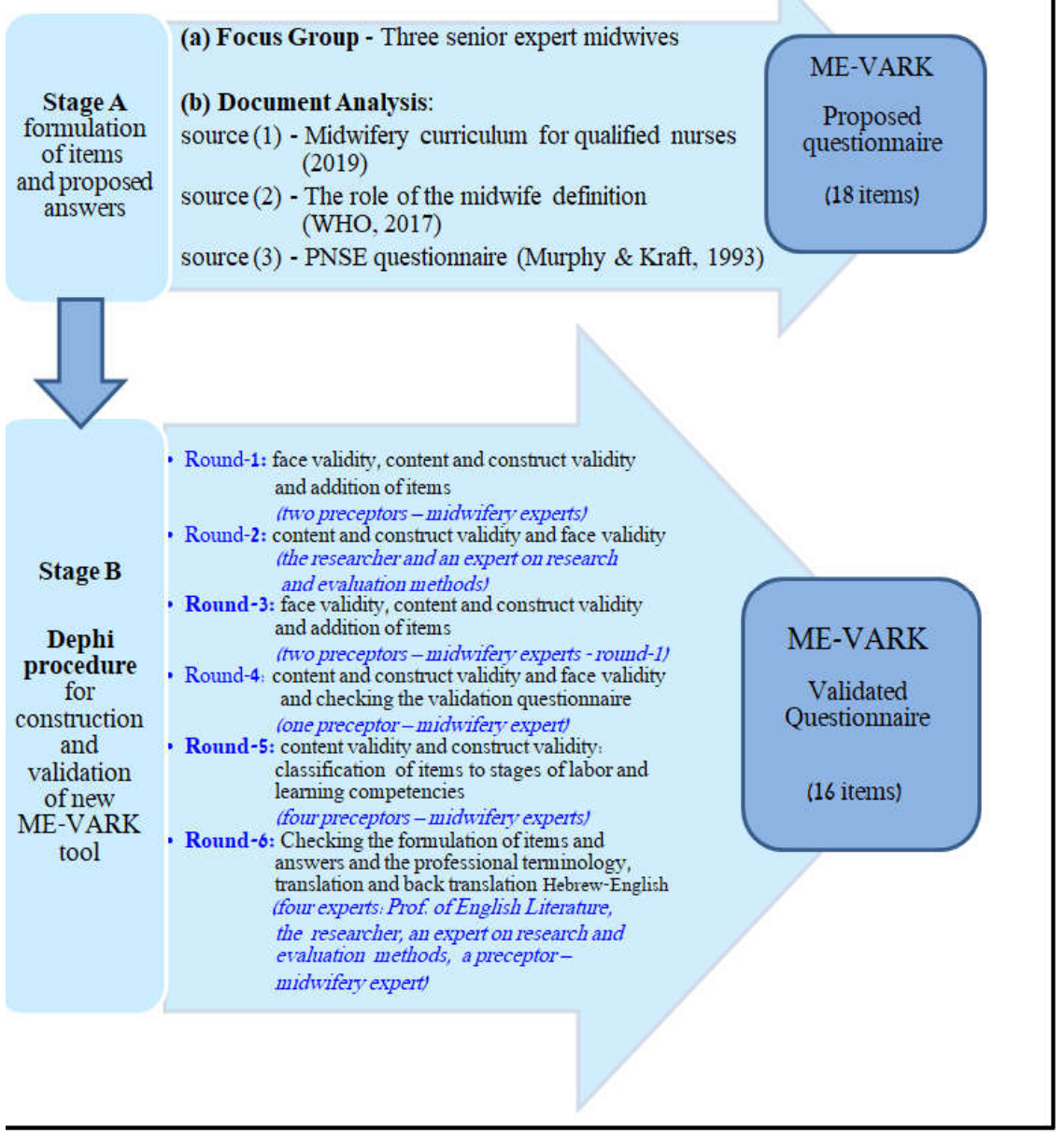

Figure 1. The design and procedure of the study

\section{Stage A-(a) Focus group}

The aim of the use of the focus group is to gather information for constructing the new questionnaire related to health education in the context of midwifery education (Kitzinger, 1994, 1996), as a preliminary stage of construction of questionnaires (Detmar et al., 2006). The group functions as a promoter of synergy 
and spontaneity by encouraging the participants to comment, explain, disagree, and share their views. Thus, experiences are shared, and opinions voiced that might not surface during individual interviews (Carey, 1994; Stewart, Shamdasani, 1990). The questions were designed by the researchers prior to the group-interview and are used to guide the discussion (Hollis, Openshaw, \& Goble, 2002; Stewart \& Shamdasani, 2007). The interview with the focus group was held at noon and lasted about an hour and a half. Following their agreement to take part in this procedure, a brief explanation of the study was given and they were given a hard copy of the original VARK questionnaire (Fleming, 2008 ${ }^{3}$ ) as an example, and an explanation of the format of a VARK question and its four possible responses (each response representing one of the four learning styles).

\section{Stage A - (b) Documental analysis}

Document analysis involves interpretation of texts and coding content into themes, in the same methods that transcripts of interviews and discussion in focus groups are analyzed (Bowen, 2009). In the current study, public records and physical evidence (O'Leary, 2014) were analyzed from three sources: The midwifery curriculum for qualified nurses (2019); the role of the midwife definition (WHO, 2017); the PNSE questionnaire (Murphy \& Kraft, 1993). Each one of the documents was carefully read by the researcher and the expert on research methods (first alone and then together) in order to produce items for the new ME-VARK questionnaire.

\section{Stage B - Delphi procedure (six-round)}

Stage B included a Delphi procedure that was carried out in six weeks (Hasson et al., 2000), to identify core competencies for advanced midwifery education. The suggestions of possible items for the adapted VARK were sent in six rounds to the panel of experts in nursing education and midwifery training, and a Ph.D. expert on research and evaluation methods, to construct, reformulate and validate the adapted version of VARK to midwifery education - ME-VARK. At each round, the expert-judge was interviewed by the researcher to help them structure and demonstrate their knowledge and experiences (Shkedi, 2003). The interviews' transcripts were analyzed using qualitative systematic content analysis - (Byron, 2013; Creswell \& Miller, 2000; Patton, 1990) in order to choose the best items, fit to describe and measure learning styles in midwifery education for the adapted ME-VARK.

\section{Population and participants}

In Israel, all midwives are already registered nurses; consequently, all midwifery preceptees work as nurses. Despite the level of nursing experience upon entry into the program, they are novices as midwifery preceptees. Currently, five education programs are actively training registered nurses to become midwives in Israel,

\footnotetext{
${ }^{3}$ See updated version: http://vark-learn.com/the-vark-questionnaire/
} 
with each program enrolling about 30 preceptees. Thus, the maximum number of participants who can be recruited in Israel each year is about 150 .

Participants - Focus Group and documental analysis: Three participants were interviewed within the focus group: two experienced (over 25 years) expertmidwives that also were experienced preceptors. Two of them work in hospitals and one midwife works at a private delivery center in the community. The documents were analyzed by the researcher and the expert on research methods.

Participants - Delphi rounds: In general, the Delphi panel sizes range from a few to fifty or more participants (Colton \& Hatcher, 2004). In the current study, ten experts participated in the Delphi rounds; they were selected according to their seniority as midwives (at least five years) and as preceptors (at least three years). In the current study, the ten expert judges participated in various rounds (a total of 15 judgements).

\section{Ethical considerations}

The researcher is positioned on a scale from being engaged to disengaged (Creswell \& Poth, 2018); The researcher is the director of an advanced nursing school. Therefore, precautions were taken under consideration of possible influences she might have on the integrity and ethics of the research. Permissions and Helsinki Committee Approval were received including permission to use PNSE questionnaire (Murphy \& Kraft, 1993) and VARK questionnaire (Fleming, 2008). Preceptees and preceptors were requested to participate in the study and express their informed consent (Byron, 2013), (a) prior to conducting the interviews and participation in the Delphi procedure, and (b) on the first page of the questionnaires. Their identities were kept confidential throughout the research.

\section{Results}

\section{Stage A-Formulation of items and proposed responses: Focus group and interviews}

This stage began with a Focus Group in which three expert midwives participated (Crotty, 1998). Following the instruction: "As an experienced preceptor, please suggest some items describing the midwifery knowledge, competences and skills which are learned via preceptorship?" - they suggested 12 items and four responses for each item representing VARK learning styles. Additionally, they were requested to write up to six more items using a "form for proposing items to examine learning styles (ME-VARK), of students during CPE in midwifery within nursing-school". This form included a brief explanation about the original VARK, a description of each learning style and two example items. Each participant filledout the form with the researcher who interviewed each one of them regarding their rationale and considerations for suggestions and wording (Byron, 2013). Following 
the documental analysis which supplemented the pool of proposed items, a total of 18 items/responses was gathered.

\section{Stage B - Six-round Delphi procedure}

Delphi round-1. The pool of 18 items was submitted to nine expert midwifery preceptors, who assessed face-validity (wording, relevance, etc.), content and construct validity (i.e., whether the list of items is exclusive and inclusive). They suggested some additional items/responses and changes, e.g., instead of using PNSE-terminology (before-during-after labor) - use of "Phase I-II-III"; items which were not specific to midwifery training were omitted. The validation-form included at the end of this round 25 -items.

Delphi round-2. The researcher and an expert on research-methods $(\mathrm{PhD})$ examined content and construct validity and relevancy to midwifery nursing, face-validity, i.e., formulation (use of the accepted terminology in obstetrics and training for midwives), during three sessions (a total of six hours). All sources of items/responses formulation were revisited to confirm that the entire questionnaire is inclusive and exclusive regarding the content realm of midwifery in nursing. The items were classified according to their wording (labor phase and competencies). At the end of this round, a new 24-item validation form was constructed for choosing 16 questions (as the original VARK) which are most related to midwifery, correcting wording and confirming (again) content and construct validity. The choise of 24 items $(50 \%$ more that needed) - was considered to be a sufficient pool of items for selection and validation.

Delphi round-3. The validation-form was used to evaluate the suggested items/responses regarding: Content validity - verifying accordance between the items/ responses - to midwifery discipline (formulation, wording); Construct validity - the proposed items/responses represent various aspects of the midwifery discipline; Inclusiveness of midwifery discipline - all items/responses are relevant to midwifery and encompass it; Exclusiveness - all items/responses are relevant only to midwifery and not to other disciplines; Face-validity - each item/response is correctly formulated, clear and easy to understand. The instructions for fillingout the form were: "The following items/responses were proposed by expertmidwives, based on relevant professional literature and guides in midwifery education. Pleas classify each item twice (please check in the relevant column. You may check more than one)".

The first item was an example of how to fill-out the form. The rest of the items were presented in the following format that is presented in Figure 2: 


\begin{tabular}{|c|c|c|c|c|c|c|c|c|c|c|c|c|c|}
\hline & & \multicolumn{3}{|c|}{\begin{tabular}{|c|} 
(A) The labor \\
stage or stages the \\
question reflects
\end{tabular}} & \multicolumn{5}{|c|}{ (B) The type of learning the question presents } & \multicolumn{4}{|c|}{$\begin{array}{l}\text { (C) The learning style the answer } \\
\text { describes }\end{array}$} \\
\hline & & $\begin{array}{c}\text { befor } \\
e \\
\text { labor }\end{array}$ & daring & $\begin{array}{l}\text { after } \\
\text { labor }\end{array}$ & \begin{tabular}{|c|}
$\begin{array}{c}\text { knowledge } \\
\text { and } \\
\text { information } \\
\text { in midwifery }\end{array}$ \\
\end{tabular} & \begin{tabular}{|} 
qualifications \\
and skills in \\
midwifery
\end{tabular} & $\begin{array}{l}\text { communication } \\
\text { with the staff } \\
\text { and the } \\
\text { parents }\end{array}$ & \begin{tabular}{|c|}
$\begin{array}{c}\text { guiding } \\
\text { pareats' } \\
\text { qualifications }\end{array}$ \\
\end{tabular} & $\begin{array}{c}\text { other (please } \\
\text { specify) }\end{array}$ & Visual & Aural & $\begin{array}{l}\text { Read- } \\
\text { write }\end{array}$ & Kinestietic \\
\hline Question 2. & $\begin{array}{l}\text { Prepare a woman } \\
\text { giving birth to epidural } \\
\text { anesthetization }\end{array}$ & & & & & & & & & & & & \\
\hline Answer 1 & $\begin{array}{l}\text { Wanch the anesthetist } \\
\text { working }\end{array}$ & & & & & & & & & & & & \\
\hline Answer 2 & \begin{tabular}{l|} 
Listen to the doctor \\
explaining to the woman \\
giving birth the epidural \\
anesthetization \\
procedure
\end{tabular} & & & & & & & & & & & & \\
\hline Answer 3 & $\begin{array}{l}\text { Read written instructions } \\
\text { and orders for } \\
\text { preparation giving } \\
\text { epidural anesthetization } \\
\text { to a waman birth to }\end{array}$ & & & & & & & & & & & & \\
\hline Answer 4 & $\begin{array}{l}\text { Practice in a simulation } \\
\text { the preparation to the } \\
\text { epidural anesthetization } \\
\text { of } 2 \text { woman giving birth }\end{array}$ & & & & & & & & & & & & \\
\hline
\end{tabular}

Figure 2. An example of an item in the validation-form of ME-VARK questionnaire

This form was submitted to the same experienced expert-midwives who participated in stage A and Delphi round-1. It was concluded that in order to ensure content and construct validity - i.e., appropriate representation of midwifery education, they should encompass meta-topics of the midwifery discipline. Thus, in addition to classification of ME-VARK items according to labor phase and competencies to be learned, the items/responses were classified according to their topic: 1. midwifery anamnesis, 2 . Knowing and understanding the meaning of pregnancy tests, 3. Perineum episiotomy, 4. Pain management, 5. Premature delivery, 6. Fetal monitoring, 7. Safe delivery 8 . Bonding (skin-to-skin, breastfeeding and labeling). After amending the items/responses, the researcher and the research methods' expert chose 16 items that were most inclusive and relevant to the midwifery discipline. Construct validity examined whether the items/responses describe a typical routine of all three labor stages. The second validation-form included 16 items/responses,

Delphi round-4. The second 16-item validation-form (figure 3) was checked by another expert judge that read carefully and in detail each item/response, and afterwards was interviewed by the researcher, who read the items out loud with her in order to assure that she understood their intended meaning (face-validity). 
The following list presents the questions and answers suggested by the expert midwives.

Please classify each question twice (check $\checkmark$ in the correct cell):

The labor stage or stages the question reflects: before labor, during labor, after labor (A)

The type of learning the question presents: knowledge and information in midwifery, qualifications and skills in midwifery, communication with the staff and the parents, guiding parents' qualifications, other (B)

In addition, please classify each of the four answers which are proposed to each question, according to the learning style the answer describes: visual, Aural, Read-write, and Kinesthetic (C).

The first question is an example:

\begin{tabular}{|c|c|c|c|c|c|c|c|c|c|c|c|c|c|}
\hline & & \multicolumn{3}{|c|}{\begin{tabular}{|c|} 
(A) The labor \\
stage or stages the \\
question reflects \\
\end{tabular}} & \multicolumn{5}{|c|}{ (B) The type of learning the question presents } & \multicolumn{4}{|c|}{$\begin{array}{l}\text { (C) The learning style the answer } \\
\text { describes }\end{array}$} \\
\hline & & \begin{tabular}{|c|} 
befor \\
$e$ \\
labor
\end{tabular} & \begin{tabular}{|l|} 
during \\
labor \\
\end{tabular} & $\begin{array}{l}\text { after } \\
\text { labor }\end{array}$ & \begin{tabular}{c|}
$\begin{array}{c}\text { lnowledge } \\
\text { and } \\
\text { information } \\
\text { in midwifery }\end{array}$ \\
\end{tabular} & \begin{tabular}{|l|} 
qualifications \\
and skills in \\
midwifery
\end{tabular} & $\begin{array}{c}\begin{array}{c}\text { communication } \\
\text { with the staff } \\
\text { and the } \\
\text { parents }\end{array} \\
\end{array}$ & \begin{tabular}{|c|} 
guiding \\
parents' \\
qualifications \\
\end{tabular} & $\begin{array}{c}\text { other (please } \\
\text { specify) }\end{array}$ & Visual & Aural & $\begin{array}{l}\text { Read- } \\
\text { write }\end{array}$ & Kinesthetio \\
\hline Question 1. & \begin{tabular}{l|} 
Prepare and treat a \\
woman giving birth \\
and the nerwborn baby \\
in a forceps delivery \\
\end{tabular} & & $\checkmark$ & & & $\checkmark$ & & & & & & & \\
\hline Answer 1 & $\begin{array}{l}\text { Watch the preceptor } \\
\text { and or relevant short } \\
\text { films }\end{array}$ & & & & & & & & & $v$ & & & \\
\hline Answer 2 & $\begin{array}{l}\text { Listen to the preceptors' } \\
\text { explanation }\end{array}$ & & & & & & & & & & $\checkmark$ & & \\
\hline Answer 3 & $\begin{array}{l}\text { Read written mstructions } \\
\text { and orders }\end{array}$ & & & & & & & & & & & $\checkmark$ & \\
\hline Answer 4 & $\begin{array}{l}\text { Practice in a simulation } \\
\text { the treatment of a woman } \\
\text { giving birth in a forceps } \\
\text { delivery }\end{array}$ & & & & & & & & & & & & $\checkmark$ \\
\hline
\end{tabular}

Figure 3. The instructions for the first and second validation form

As a result of this validation process some changes were introduced: One irrelevant item was omitted because it describes a period of time which is not under the responsibility of the midwife (content validity); the items were rephrased focusing on clinical reasoning - and not other competencies (e.g., instead of "deciding to give Pethidine..." - "Giving Pethidine according to the guidelines"); Responses which described kinesthetic learning style were reworded to describing action (e.g., "to suggest and apply" was changed to "practice in simulation").

Delphi round-5. The validation-form was submitted to two expert-judges. Following all comments of the judges, the following classification was determined (content and construct validity): 
Table 1. Labor phases and learning competencies

\begin{tabular}{|c|c|c|c|c|c|c|}
\hline \multicolumn{3}{|c|}{ Labor Phase } & \multicolumn{4}{|c|}{ Learning Competencies } \\
\hline $\begin{array}{c}\mathrm{P} 1= \\
\text { phase I }\end{array}$ & $\begin{array}{c}\mathrm{P} 2= \\
\text { phase II }\end{array}$ & $\begin{array}{c}\mathrm{P} 3= \\
\text { phase III }\end{array}$ & $\begin{array}{c}\mathrm{Cl}= \\
\text { Theoretical } \\
\text { preliminary } \\
\text { Knowledge } \\
\text { in midwifery }\end{array}$ & $\begin{array}{c}\mathrm{C}= \\
\text { qualifications } \\
\text { and skills } \\
\text { in midwifery }\end{array}$ & $\begin{array}{c}\mathrm{C} 3= \\
\text { communication } \\
\text { with the staff }\end{array}$ & $\begin{array}{c}\mathrm{C} 4= \\
\text { communication } \\
\text { with the mother, } \\
\text { family and } \\
\text { significant others, } \\
\text { and guidance }\end{array}$ \\
\hline
\end{tabular}

A few amendments were introduced to the wording of the items/responses, e.g., "Providing safe care for mother and infant immediately following birth including weight and labeling" was changed to "identification and labeling", because it focuses on bonding between mother and baby - and weighing is a technical skill. In accordance all items' responses were amended as well.

Delphi round-6. The ME-VARK questionnaire was translated into English and back into Hebrew by a professor of English literature and by an expert in research and evaluation methods $(\mathrm{PhD})$. In addition, the wording was compared to the Myles textbook for midwives (Marshall \& Raynor, 2014) and relevant curricula in English. The researcher and the expert on research methods $(\mathrm{PhD})$ reviewed again all items/responses and decided that each item should begin with a gerund (e.g., "performing") as with most items in the original VARK (Fleming, 2001, 2008) and that the order of the responses to each item should be presented in the exact order of the original VARK questionnaire. Then, it was submitted again to the judge who participated in the 1st\&3rd Delphi rounds. She noted that instead of using "to practice" in the responses that represent the Kinesthetic learning style - the wording should be "performing... in real time or in simulation". This change of the verb from infinitive construct (infinitive) to verbal noun (gerund) was introduced into the Hebrew and English ME-VARK questionnaires.

\section{The final validated ME-VARK}

The final ME-VARK questionnaire included 16 items (as the original VARK), describing knowledge and competencies that are learned during midwifery training, through the interaction between the preceptor and the preceptee. For each item, four responses were worded which describe the four learning styles. The responses were presented in the same order of learning styles as in the original VARK questionnaire, to maintain construct validity. 


\begin{tabular}{|c|c|}
\hline \multicolumn{2}{|c|}{$\begin{array}{l}\text { Item number-classification } \\
\text { V/ARK response }\end{array}$} \\
\hline $1-\mathrm{P} 1 \mathrm{C} 124$ & (1) Performing individualized maternal health assessment \\
\hline Kinesthetic & 1. Receiving a woman in the labour unit in real time and or through simulation \\
\hline Aural & 2. Listening to the preceptors explanations \\
\hline Read/Write & 3. Reading written guideline, instructions and the relevant text books \\
\hline Visual & 4. Watching the preceptor and or relevant short videos \\
\hline 2-P12C124 & (2) Performing vaginal examination of a woman in labour \\
\hline Visusal & 1. Watching films that demonstrate the examimation \\
\hline Aural & 2. Listening to the preceptor's explanations regarding the procedure of performing the examimation \\
\hline Read/Write & 3. Reading guidelimes and instructions regarding performing the examination \\
\hline Kinesthetic & 4. Practicing the examination in real time and or through simulation \\
\hline 3-P1C1234 & (3) Apply a fetal monitor on a woman in labor for the first time \\
\hline Kinesthetic & 1. Placing a fetal monitor on a woman in real time and/or through simulation \\
\hline Visual & 2. Watching a film that demonstrates the correct placement of a fetal monitor \\
\hline Read Write & 3. Reading guidelimes and instructions regarding the correct placement of a fetal monitor \\
\hline Aural & 4. Listening to the preceptor's explanations \\
\hline 4-P12C124 & (4) Interpret fetal monitor strips \\
\hline Kinesthetic & $\begin{array}{l}\text { 1. Placing a woman in labour on a fetal monitor and interpreting the findings, in real time or by } \\
\text { simulation }\end{array}$ \\
\hline Aural & $\begin{array}{l}\text { 2. Listening to the explanations of the preceptor and other members of the team as they interpret the } \\
\text { displayed results of the fetal monitor strips }\end{array}$ \\
\hline Visugal & 3. Watching the preceptor and other members of the team interpret the fetal monitor strips \\
\hline Read/Write & 4. Looking at the displayed results and reading textbook that explain how to interpret them \\
\hline 5-P123C1234 & (5) Recognizes the stages of labour \\
\hline Aural & 1. Listening to the explanations of the preceptor as to how to identify the stages of labor \\
\hline Visual & 2. Watching a film that demonstrates the stages of labour \\
\hline Kinesthetic & $\begin{array}{l}\text { 3. Performmg a vaginal exammation } \\
\text { in real time and or through simulation }\end{array}$ \\
\hline Read/Write & 4. Reading explanations in textbooks or recognizing the stages of labor \\
\hline 6-P123C1234 & (6) Skilled care of the woman and fetus during pre-mature labor with preceptor's supervision \\
\hline Kinesthetic & 1. Practicing through simulation care of the woman and fetus during pre-mature labor \\
\hline Read/Write & 2. Reading $m$ the textbook how to care for a woman during pre-mature labour \\
\hline Visual & 3. Watching the preceptor administer skilled care to the woman and fetus during pre-mature labour. \\
\hline Aural & $\begin{array}{l}\text { 4. Listening to preceptor's consultation and explanations regarding, observation and exammation of the } \\
\text { woman during pre-mature labor }\end{array}$ \\
\hline 7-P123C1234 & (7) providing adequate interventions when protracted labor is identified \\
\hline Kinesthetic & 1. Implementing suitable solutions for protracted labor with a preceptor and the woman's cooperation \\
\hline Aursal & 2. Discussing probable solutions with the preceptor in cases when protracted labor is identified \\
\hline Visual & 3. Watching tutorial films of birth imcluding protracted labor and its possible solutions \\
\hline Read/Write & 4. Reading textbooks and articles that describe possible solutions for protracted labor \\
\hline 8-P1C12 & (8) Clinical decision making for pethidine administration guidelines \\
\hline Read/Write & 1. Reading the guidelimes for pethidime administration \\
\hline Kinesthetic & 2. Making decisions regarding the administration of pethidime in real time and or through simulation \\
\hline Visual & $\begin{array}{l}\text { 3. Watching the preceptor decide and administer pethidme, along with an informative explanation to } \\
\text { the woman }\end{array}$ \\
\hline Aural & $\begin{array}{l}\text { 4. Discussing the preceptor's reasons for pethidine admmistration and listening to her give an } \\
\text { informative explanation to the woman }\end{array}$ \\
\hline 9-P123C2 & (9) Identify post-partum hemorrhage and treatment \\
\hline Read/Write & 1. Reading in textbooks about care for the woman with postpartum hemorrhage \\
\hline Aural & 2. Discussing with the preceptor the care of a woman with postpartum hemorrhage \\
\hline Kinesthetic & 3. Treatment of postpartum hemorrhage in real time and or through simulation \\
\hline Visual & 4. Watching the preceptor care for a woman with postpartum hemorrhage \\
\hline
\end{tabular}

Figure 4. The final ME-VARK after validation and classification into labor stages and midwifery competencies that are learned via preceptorship 


\begin{tabular}{|c|c|}
\hline \multicolumn{2}{|c|}{$\begin{array}{l}\text { Item number-classification } \\
\text { V/A/R/K response }\end{array}$} \\
\hline 10-P12C12 & (10) Identify signs of fetal distress \\
\hline Kinesthetic & $\begin{array}{l}\text { 1. Identification of signs of fetal distress by reading fetal monitor strips in real time and or through } \\
\text { simulation }\end{array}$ \\
\hline Visual & 2. Watching the preceptor and other team members identify signs of fetal distress \\
\hline Read/Write & 3. Reading about the signs of fetal distress in textbooks and preparing a written summary \\
\hline Aural & $\begin{array}{l}\text { 4. Discussing with the preceptor and or listening to a discussion between other team members about } \\
\text { the signs of fetal distress }\end{array}$ \\
\hline P23C1234 & (11) Enabling a safe birth environment for mother and her infant \\
\hline Visual & 1. Observing the preceptor actions that enable a safe birth \\
\hline Read/Write & 2. Reading in textbooks how to maintain a safe birth for mother and her infant \\
\hline Aural & $\begin{array}{l}\text { 3. Listening to the preceptor's explanations about necessary procedures for maintaining safety of } \\
\text { mother and child }\end{array}$ \\
\hline Kinesthetic & 4. Management of safe labor in real time and or through simulation \\
\hline $12-\mathrm{P} 3 \mathrm{C} 124$ & $\begin{array}{l}\text { (12) Providing safe care for mother and infant immediately following birth including } \\
\text { identification and labeling }\end{array}$ \\
\hline Aural & $\begin{array}{l}\text { 1. Listening to the preceptor's explanations about necessary procedures for mother and infant } \\
\text { immediately following birth including identification and labeling }\end{array}$ \\
\hline Read/Write & $\begin{array}{l}\text { 2. Reading the Ministry of Health's guidelines on providing appropriate care including identification of } \\
\text { mother and her infant immediately following birth }\end{array}$ \\
\hline Visual & $\begin{array}{l}\text { 3. Watching the preceptor provide appropriate care including identification of the mother and her } \\
\text { infant immediately following birth }\end{array}$ \\
\hline Kinesthetic & 4. Care giving to the infant immediately following birth in real time and or through simulation \\
\hline 13-P3C1234 & $\begin{array}{l}\text { (13) Assess general condition of the newborn following birth including determining Apgar } \\
\text { scoring }\end{array}$ \\
\hline Kinesthetic & 1. Practicing with the preceptor assessment of the newborn including determination of Apgar scoring \\
\hline Aural & $\begin{array}{l}\text { 2. Listening to the preceptor's explanations regarding assessment of the newbom including the } \\
\text { determination of Apgar scoring }\end{array}$ \\
\hline Read/Write & $\begin{array}{l}\text { 3. Reading in relevant textbooks descriptions explaining the assessment of the newbom following birth } \\
\text { including the determination of Apgar scoring }\end{array}$ \\
\hline Viscal & $\begin{array}{l}\text { 4. Watching movies that demonstrate assessment of the newbom following birth including the } \\
\text { determination of Apgar scoring }\end{array}$ \\
\hline 14-P3C124 & (14) Encourage early bonding of parent-baby with emphasis on skin to skin and breastfeeding \\
\hline Kinesthetic & $\begin{array}{l}\text { 1. Practicing encouraging and early bonding of the parent-baby unit with emphasis on skin to skin and } \\
\text { breastfeeding }\end{array}$ \\
\hline Read/Write & $\begin{array}{l}\text { 2. Reading in textbooks how to encourage early bonding of the parent-baby unit with emphasis on skin } \\
\text { to skin and breastfeeding }\end{array}$ \\
\hline Aural & $\begin{array}{l}\text { 3. Listening to the preceptor's explanations regarding the best ways encouraging early bonding of the } \\
\text { parent-baby unit with emphasis on skin to skin and breastfeeding }\end{array}$ \\
\hline Visual & $\begin{array}{l}\text { 4. Watching the preceptor encourage early bonding of the parent-baby unit with emphasis on skin to } \\
\text { skin and breastfeeding }\end{array}$ \\
\hline 15-P3C4 & $\begin{array}{l}\text { (15) Helping initiate early breastfeeding as soon as possible following birth, help finding safe and } \\
\text { appropriate positioning }\end{array}$ \\
\hline Kinesthetic & 1. Applying what was learned in guiding the mother in early breastfeeding with help and support \\
\hline Alural & 2. Listening to the preceptor help and support the mother in early breastfeeding after birth \\
\hline Read/Write & $\begin{array}{l}\text { 3. Reading guidelines about how to help and support a mother in breastfeeding after birth and } \\
\text { summarize in writing }\end{array}$ \\
\hline Visual & 4. Watching the preceptor help and support the mother in early breastfeeding after birth \\
\hline 16-P3C2 & $\begin{array}{l}\text { (16) Guiding the woman in care for her perineum following birth with emphasis on treating the } \\
\text { stitches }\end{array}$ \\
\hline Visual & $\begin{array}{l}\text { 1. Watching films that demonstrate guiding the woman to care for the perineum following birth } \\
\text { including stitches }\end{array}$ \\
\hline Aural & $\begin{array}{l}\text { 2. Listening to the preceptor and asking her to explain how she guide the women to care for the } \\
\text { perimeum following birth including stitches }\end{array}$ \\
\hline Read/Write & 3. Reading guidelines that focus on care for the perineum following birth including stitches \\
\hline Kinesthetic & $\begin{array}{l}\text { 4. Practicing in real time and through simulation guiding the woman to care for the perineum } \\
\text { following birth including stitches }\end{array}$ \\
\hline
\end{tabular}

Figure 4 (continued). The final ME-VARK after validation and classification into labor stages and midwifery competencies that are learned via preceptorship 
The instructions for filling-out the ME-VARK were formulated similar to the original VARK instructions and adapted to preceptors' and preceptees' questionnaires.

\section{Discussion}

According to the first research question, in the current study items that are suitable to measure knowledge, competencies and learning styles in midwifery education were identified. Following an in-depth literature review, and to the best of our knowledge, this is the first attempt to adapt and validate the VARK questionnaire to a specific professional discipline, in the current study midwifery education.

The validation procedure of the ME-VARK questionnaire was carried out by expert-judges, and included a focus group, documental analysis and a six-round Delphi procedure. Following the stages of validation, it may be concluded, that (a) the adapted ME-VARK is relevant to midwifery education and encompasses the main labor stages, the central types of learning via preceptorship, and the essential topics in midwifery profession (exclusiveness). This aspect ensures that midwifery education will produce qualified, competent, and autonomous midwives (The World Health Organization, 2000; Lukasse et al., BMC Medical Education, 2017). This aspect contributes to midwifery education a professional midwife with strong prenatal-efficacy and solid professional identity with clear understanding not only the core of the profession, but also its boundaries; (b) all items in the adapted ME-VARK are relevant only to midwifery education and not to specifically to other nursing specialties (inclusiveness).

In response to the second research question, the adapted ME-VARK was found to have all psychometric attributes: content and construct validity, as well as face validity.

The innovation and unique contribution of the study is twofold; first, it constructs a systematic, evidence-based procedure to adapt the VARK questionnaire to additional professional disciplines (figure 1), and second, it adapts and validates VARK to the professional discipline of midwifery education - ME-VARK.

Research on matched preceptor-preceptee learning styles may promote midwifery education and training in the clinical setting by successfully integrating theory into the clinical practice. In addition, it may also contribute to promoting the professional development of the preceptors themselves.

In further research it is suggested to further validate this new ME-VARK questionnaire in additional samples of preceptors and preceptees (in Israel and other countries). It is also suggested that the systematic, evidence-based procedure developed in this study be used to adapt VARK to additional disciplines. In intervention research, it is recommended to develop and apply workshops for individual training according to specific learning styles profiles that may be identified via the ME-VARK questionnaire. 
Preceptors should be aware that it is highly important to match their teaching methods and requested assignments to their students' unique learning styles.

\section{References}

Alkhasawneh, I. M., Maryyan, M. T., Alashram.S, \& Yousef, H. Y. (2008). Problem based learning (PBL): Assessing learners' learning preferences using VARK. Nurse Education Today, 28(5), 572-579. DOI 10:1016/J.nedt.2007.09.012

Altman, T. K. (2006). Preceptor selection, orientation, and evaluation in baccalaureate nursing education. International Journal of nursing Education, 3(1), 1-15.

Bandura, A. (1977). Social learning theory. Englewood cliffs: Prentice Hall.

Benner, P. (2001). From novice to expert: Excellence and power in clinical nursing practice. Upper Saddle River: Prentice Hall. DOI: 10.12968/bjom.2016.24.8.582

Benoit, C., Wrede, S., Bourgeault I., Sandall, J., De Vries, R., \& van Teijlingen, E. R. (2005). Understanding the social organisation of maternity care systems: midwifery as a touchstone. Sociology of Health \& Illness, 27(6), 722-737.

Biddle, B. J. (1986). Recent developments in role theory. Annual Review in Sociology, $12,67-92$.

Bluff, R., \& Holloway, I. (2008). The efficacy of midwifery role models. Midwifery 24, 301-309.

Bowen, G. A. (2009). Document analysis as a qualitative research method. Qualitative Research Journal, 9(2), 27-40.

Byron, A. (2013). Social research methods (4th Edition). New York: Oxford University.

Carey M. (1994). The group effect in focus groups: Planning, implementing, and interpreting focus group research. In: J. Morse (ed.). Critical Issues in Qualitative Research Methods. London: Sage.

Carlson, E., Wann-Hansson, C. K., \& Pilhammar, E. (2009). Teaching during clinical practice: Strategies and techniques used by preceptors in nursing education. Nurse education today 29(5), 522-6

Cavanagh, S. J., \& Coffin, D. A. (1994). Matching instructional preference and teaching styles: A review of the literature. Nurse Education Today, 29, 202-207.

Colton, S., \& Hatcher, T. (2004). The web-based Delphi research technique as a method for content validation in HRD and adult education research. (Retrieved June 28, 2009). Available: http://www.mpc.edu/FacultyStaff/SharonColton/Documents/ Establishing\%20the\%20Delphi\%20Technique.pdf

Creswell, J. W. (2014). Research Design: Qualitative, quantitative and mixed methods approaches $\left(4^{\text {th }}\right.$ ed.) Los Angeles: Sage.

Creswell, J. W., \& Miller, D. L. (2000). Determining validity in qualitative inquiry. Theory into Practice, 39, 124-130.

Creswell, J. W., \& Poth, N. P. (2018). Qualitative inquiry and research design: choosing among five approaches (4th Edition). Los Angeles: Sage.

Crotty, M. (1998). The foundations of social research: meaning and perspectives in the research process. St. Leonards, NSW: Allen \& Unwin.

Detmar, S.B., Bruil, J., Ravens-Sieberer, U., Gosch, A., Bisegger, C., \& The European KIDSREEN Group. (2006). The use of focus groups in the development of the KIDSREEN HRQL Questionnaire. Quality of Life Research, 15, 1345-1353. 
Eraut, M. (2007). Early career learning at work teaching and learning research programme research briefing. London, UK: www.tlrp.org.

Felder, R. M., \& Barnett, R. (2005). Understanding student differences. Journal of Engineering Education, 31(1), 57-72.

Fleming, N. D. (2001). Teaching and learning styles: VARK strategies (1st ed., pp. 128). Christchurch, New Zealand: N. D. Fleming.

Fleming, N. D. (2008). VARK. A guide to learning styles .Retrieved from http://VARKlearn.com

Happell, B. (2009). A model of preceptorship in nursing: Reflecting the complex functions of the role. Nursing Education Perspectives, 30(6), 372-376. doi:10.1043/15365026-30.6.372

Hardy, R., \& Smith, R. (2001). Enhancing staff development with a structural preceptor programme. Journal of Nursing Care Quality, 15, 9-17.

Hardymen, R., \& Hickey, G. (2001). What do newly-qualified nurses expect from preceptorship? exploring the perspective of the preceptee. Nurse Education Today, 21(1), 58-64. doi:10.1054/nedt.2000.0511

Hasson, F., Keeney, S., \& Mckenna, H. (2000). Research guidelines for the Delphi survey technique. Journal of Advanced Nursing, 32, 1008-1015.

Hollis, V., Openshaw, S., \& Goble, R. (2002). Conducting focus groups: Purpose and practicalities. British Journal of Occupational Therapy, 65, 1-8.

Holton, G. (2004). Robert K. Merton - Biographical Memoirs. Proceedings of the American Philosophical Society, 148(4), 506-517

ICM - International Confederation of Midwives (2018). Definition of the midwife. Retrieved from: https://www.internationalmidwives.org/our-work/policy-and-practice/icmdefinitions.html

Kitzinger J. (1994). The methodology of Focus Groups: the importance of interaction between research participants. Sociology of Health \& Illness, 16(1), 103-121.

Kitzinger J. (1996). Introducing focus groups. In N. Mays, \& C. Pope (eds), Qualitative Research in Health Care. London: B. M. J. Publishing Group.

Lambert, V, \& Glacken, M. (2006). Clinical education facilitators' and post-registration paediatric student nurses' perceptions of the role of the clinical education facilitator. Nurse Education Today, 26(5), 358-66.

Leite, W. L., Svinicki, M., \& Shi, Y. (2010). Attempted validation of the scores of the VARK: learning styles inventory with multitrait-multimethod confirmatory factor analysis models. Educational and Psychological Measurement, 70(2), 323-339. doi:10.1177/0013164409344507

Lukasse, M., Lilleengen, A. M., Fylkesnes, A. M., \& Henriksen, L. (2017). Norwegian midwives' opinion of their Midwifery Education - a mixed methods study. BMC Medical Education, doi https://doi.org/10.1186/s12909-017-0917-0

Marshall, E. J. \& Raynor, M. (2014 ). Myles textbook for midwives. London, UK: Elsevier. Merton, K. (1957) Social theory and social structure. New York: Free Press

Murphy, C., \& Kraft, L. (1993). Development and validation of the perinatal nursing self-efficacy scale (PNSE). Scholary Inquiry for Nursing Practice, 7(2), 95-106.

Myrick, F. (2002). Preceptorship and critical thinking in nursing education. Journal of Nursing Education, 41(4), 154-164.

Myrick, F., \& Yonge, O. J. (2001). Creating a climate for critical thinking in the preceptorship experience. Nurse Education Today, 21(6), 461-467. doi:http//dx.doi.org.10.1054/ nedt.2001,0593 
Myrick, F., \& Yonge, O. J. (2004). Enhancing critical thinking in the preceptorship experience in nursing education. Journal of advanced nursing, 45(4), 371-380.

Nielsen, K., Finderup, J., Brahe, L., Elgaard, R. \& Elsborg, A. M. Engell-Soerensen, V., et al. (2017). The art of preceptorship: A qualitative study. Nurse Education Practice, 26, 39-45. doi: 10.1016/j.nepr.2017.06.009

O'Leary, Z. (2014). The essential guide to doing your research project (2nd ed.). Thousand Oaks, CA: SAGE.

Patton M. Q. (1990). Qualitative evaluation and research methods (2nd ed.). Newbury Park, California: Sage.

Perry, B. (2009). Role modeling excellence in clinical nursing practice. Nurse Education in Practice, 9, 36-44. doi:10.1016/JNEPR.2008.05.001

Peyman, H., Sadeghifar, j., Kahajvikhan, j., Yassemi, M., Rasool, M., Yaghoubi, Y. M., \&. Karim. H. (2014). Using VARK approach for assessing preferred learning styles of first year medical sciences students: A survey from Iran. Journal of Clinical and Diagnostic Research, 8(8), GC01-GC04. doi:10.7860/JCDR/2014/8089.4667

Phillips, D. J. (2002). A discursive model of professional identity formation and cultural agency in midwifery education: A framework to guide practice. Doctoral dissertation, The University of Melbourne, Melbourne.

Phillips, D. J., \& Hayes, B. (2006(. Moving towards a model of professional identity formation in midwifery through conversations and positioning theory. Australian Journal of Adult Learning, 46(2), 224-242.

Phillips, D., R., \& Fawns, \& Hayes, B. (2002). From personal reflection to social positioning: the development of a transformational model of professional education in midwifery. Nursing Inquiry, 9(4), 239-249

Phillips, E. (2016). Nurse preceptors'perceptions of preparedness in the preceptor role. Nursing Theses and Capstone Projects Hunt School of Nursing, Gardner-Webb University.

Power, A., \& Ewing, K. (2016). Midwifery preceptorship: The next chapter. British Journal of Midwifery, 24(8), 582584.

Shamian, J., \& Inhaber, R. (1985). The concept and practice of preceptorship in contemporary nursing: A review of pertinent literature. International Journal of Nursing Studies, $22,79-88$.

Shkedi, A. (2003). Words that try to touch: Qualitative research - Theory and application. Tel-Aviv: Ramot. (In Hebrew)

Stewart D., \& Shamdasani P. (1990). Focus groups: Theory and practice. Beverly Hills, CA: Sage Publications.

The Midwifery program curriculum (2019). Ministry of Health - Nursing Division Israel.

The World Health Organization. (2000). Health System: Improving Performance. Retrieved from Geneva: http://www.who.int/whr/2000/en/.

WHO (2017). Nursing and midwifery in the history of the World Health Organization 1948-2017. WHO Expert Committee on midwifery Training: first report. Geneva: World Health Organization; 1954 (WHO Technical Report Series, No. 93).

Zilembo, M., \& Monterosso, L. (2008). Towards conceptual framework for preceptorship in the clinical education of undergraduate nursing students. Contemporary Nurse, $30(1), 89-94$. 